\title{
Nitrogen Biofixing Bacteria Compensate for the Yield Loss Caused by Viral Satellite RNA Associated with Cucumber Mosaic Virus in Tomato
}

\author{
N. H. Dashti ${ }^{1}$ M. S. Montasser ${ }^{1, *}$, N. Y. Ali ${ }^{1}$, R. G. Bhardwaj ${ }^{1}$ and D. L. Smith ${ }^{2}$ \\ ${ }^{\prime}$ Department of Biological Sciences, Faculty of Science, University of Kuwait, P. O. Box 5659, Safat 13060, Kuwait \\ ${ }^{2}$ Plant Science Department, McGill University, Ste. Anne de Bellevue, Quebec, Canada H9X $3 V 9$
}

(Received on April 15, 2007; Accepted on May 17, 2007)

To overcome the problem of the yield reduction due to the viral satellite mediated protection, a culture mix of three nitrogen-fixing bacteria species of the genus Azospirillum (A. brasilienses N040, A. brasilienses SP7, and $A$. lipoferum MRB16), and one strain of cyanobacteria (Anabena oryzae Fritsch) were utilized as biofertilizer mixture in both greenhouse and field experiments. When protected plants were treated with biofertilizer mixtures, the fruit yield of biofertilized plants increased by $48 \%$ and $40 \%$ in a greenhouse and field experiment, respectively, compared to untreated plants inoculated with the protective viral strain alone. Polyacrylamide gel electrophoresis (PAGE) analysis of total nucleic acid (TNA) extracts revealed that biofertilization did not affect the accumulation of the viral satellite RNA (CARNA 5) that is required for plant protection against other destructive viral strains of CMV. The yield increment was a good compensation for the yield loss caused by the use of the protective viral strain associated with CARNA 5.

Keywords : Biofertilizers, Viral satellite RNA, CMV, CARNA 5

Recently, there has been a growing interest in the use of viral satellite RNAs, such as Cucumber mosaic virus (CMV)-associated RNA 5 (herein abbreviated CARNA 5), as biological control agents against severe strains of CMV (Gallitelli et al., 1991; Montasser et al., 1991, 2006). However, protected plants with a combination of a mild strain of CMV, as a helper virus, and CARNA 5 as a biological control agent resulted in about $15-20 \%$ yield loss (Montasser et al., 1991). To overcome the problem of yield reduction, applications of biofertilizers, consisting of a mixture of nitrogen fixing bacteria of the genus Azospirillium and cyanobacteria, were used. Inoculation of plants with Azospirillum spp. strains increased the yield of many cereal and vegetable crops (Kapulnik et al., 1983; Kotob et al., 1990; Caballero-Mellado et al., 1993;

*Corresponding author.

Phone) +965-6694673, FAX) +965 561-6421

E-mail) m_montasser@hotmail.com
Thakuria et al., 2004). It was reported that growthstimulating compounds and nitrogen-fixation are the reasons for the yield increases (Rodgers et al., 1979).

Growth promotion of tomato plants by rhizobacteria (Azospirillum sp., Azotobacter chroococcum, and Pseudomonas fluorescens) and imposition of energy stress via the pathogen Rhizoctonia solani, studied by Gupta et al., 1995, also resulted in seedling emergence rate, improved plant growth and potential for biocontrol of Rhizoctonia damping-off.

Studies have examined the effect of Azospirillum inoculation on several crops. Burris (1977) ran a field trial using nineteen different varieties or species of plants, fourteen of which showed a positive yield response, while the remaining five showed a negative response, to inoculation with Spirilum lipoferum. Numerous other studies have also demonstrated that the response to inoculation is extremely variable.

The main objective of this work was to determine the efficacy of biofertilizers on tomato fruit yield in order to compensate for the yield loss caused by the use of satellitemediated protection (Montasser et al., 1991; 2006). Greenhouse and field experiments were designed to examine the effects of Azospirillum and cyanobacteria on number and fresh weight of tomato fruits, nitrogen contents, and dry weight of tomato plants inoculated with and without the protective strain of CMV associated with CARNA 5.

\section{Materials and Methods}

Virus source and maintenance. CMV strain containing CARNA 5 used as a biological control agent was maintained and propagated in tomato (Lycopersicon esculentum cultivar UC82B) plants. Inoculated tomato plants were kept in 20-cm-diameter pots containing a mixture of soil, peat moss, and vermiculite $(2: 1: 1, \mathrm{v} / \mathrm{v})$ in an insect-proof greenhouse where the temperature ranged from 24 to $35 \mathrm{C}$.

Virus purification and inoculum preparation. CMV strain was purified from 7-14 day old infected tomato plants according to Lot et al., 1972 with some modifications. Plant 
tissues were blended together with chloroform and $0.5 \mathrm{M}$ Na-citrate-citric acid buffer ( $\mathrm{pH}$ 6.5) containing $0.1 \%$ thioglycolic acid (TAG) in the ratio of $1 \mathrm{~g}$ tissue $/ 2 \mathrm{~mL}$ chloroform $/ 2 \mathrm{~mL}$ buffer. The homogenate was filtered, squeezed through cheesecloth and then clarified by centrifugation at $5900 \times \mathrm{g}$ for $10 \mathrm{~min}$. The supernatant volume was measured and stirred with $10 \%$ PEG $8000(\mathrm{w} / \mathrm{v})$ for 15 $\min$ at $4^{\circ} \mathrm{C}$. The mixture was cooled for $30-40 \mathrm{~min}$ in an ice bath followed by centrifugation at $13,200 \times \mathrm{g}$ for $20 \mathrm{~min}$. Pellets were resuspended in $0.05 \mathrm{M}$ Na-citrate-citric acid buffer at $\mathrm{pH} 7$ containing $2 \%$ Triton $\mathrm{X}-100$, and then submitted to a low speed centrifugation at $5,900 \times \mathrm{g}$ for 5 min. The supernatant was centrifuged at $85,000 \times \mathrm{g}$ for 4 hours. Pellets were resuspended in water overnight at $4^{\circ} \mathrm{C}$, homogenized with a glass rod, and then clarified by a $5 \mathrm{~min}$ centrifugation at $5,900 \times \mathrm{g}$. The supernatant was diluted in $0.05 \mathrm{M} \mathrm{Na}$-citrate-citric acid buffer $\mathrm{pH} 7$. To determine the virus purity, absorbance readings were taken at 260 and 280 $\mathrm{nm}$. Viral RNA genome was further extracted from purified virus preparations using the chloroform/phenol extraction method described by White and Kaper, 1989 and reported by Montasser et al., 1999, 2006. The extracted viral RNA was used as an inoculum for the mechanical transmission of the protective strain.

Mechanical inoculation of the protective viral strain and biofertilization. Protective strain was mechanically inoculated on the cotyledonary leaves of tomato seedlings.

Inoculations with extracted viral RNA were made by rubbing, with a cotton swap, the cotyledonary leaves of tomato plants that had previously been dusted with 600 mesh Carborundum (Montasser, 1999). Immediately after inoculation, the leaves were rinsed with distilled sterile water. Test plants were kept in $20-\mathrm{cm}$ diameter pots containing a mixture of soil, peat moss and vermiculite $(2: 1: 1, v / v / v)$ in a greenhouse where the temperature ranged from 24 to $35 \mathrm{C}$. Biofertilizer mixtures $(12 \mathrm{ml}$ culture suspension/test plant) of cyanobacterium and/or $A z o-$ spirillum spp. mix were inoculated into the soil by using a sterile-glass pipette. Each treatment was applied into the soil adjacent to the crown area and to the root-system zone of each test plant. Test plants grown either in pots, in the greenhouse or in the field were treated according to the experimental design for each treatment.

Bacterial strains and biofertilizer inoculum preparations. A culture mix of Azospirillum brasilliensis strains N040 and Sp7, and Azospirillum lipoferum strain MRB16 (kindly provided by Dr. S. Kotob, USDA, Maryland, USA), was used separately or in combinations with cyanobacterial strain of Anabaena oryzae Fritsch (kindly provided by Dr. F. Hashem, University of Maryland, College Park MD,
USA) as a biofertilizer inoculum. Biofertilizer treatments were used either separately or in combinations with protected (preinoculated with the protective viral strain containing CARNA 5) and non-protected healthy tomato plants as a control in both greenhouse and field experiments.

Experimental designs and statistical analyses. The effect of biofertilization on the yield of tomato plants inoculated with the protective strain of CMV associated with CARNA 5 was determined by measuring plant growth under both greenhouse and field conditions. Eight different treatment variables were used in both greenhouse and field experiments with healthy/negative control plants $(H)$, plants preinoculated with the protective viral strain (V) to serve as a positive control, cyanobacterium treated plants (C), Azospirillum treated plants (A), plants treated with $\mathrm{C}+\mathrm{A}, \mathrm{C}$ $+\mathrm{V}, \mathrm{A}+\mathrm{V}$, and $\mathrm{A}+\mathrm{C}+\mathrm{V}$ (Fig. 1C), as this set up is shown in Fig. 1.C. Ten plants were tested for each treatment and replicated three times in 2 different sets of greenhouse and field experiments (i.e. 10 plants $\times 8$ treatments $\times 3$ replicas $\times 2$ sets $=480$ test plants). The effect of biofertilizers on tomato plants grown in the greenhouse was determined by measuring plant growth, fruit yield and nitrogen content. In addition, $\mathrm{pH}$ of the tomato fruits was determined in two sets of three replications in greenhouse experiments. Dry weight and nitrogen contents were assessed on a per plant basis. In the field experiment, fruit number and fruit fresh weight (average yield) were measured per ten plants. Average tomato yield was compared to healthy untreated controls by measuring average fruit number and average fruit yield per 10 plants in 3 replicas that were repeated twice as in 2 sets of experiments. A complete randomized block design was used for both greenhouse and field experiments. Fruit yield assessment, fresh and dry weight, nitrogen contents and fruit $\mathrm{pH}$ data were statistically analyzed for each treatment. Fruit yield values were calculated for each treatment with the mean of healthy untreated plants as baseline. Data collected at the final reading for each treatment were used for statistical analyses using Student's $t$ test to compare treatments and treatments with untreated-control plants. Least significant differences (LSD) were determined for tomato fruit yield and for the number of fruits.

Polyacrylamide gel electrophoresis and northern hybridization. Purified viral RNA preparations and total nucleic acid extracts (TNA), prepared from random leaf samples taken four times during the season from different treatments, were analyzed by electrophoresis on $6 \%$ polyacrylamide (39:1 acrylamide: bis-acrylamide containing $7 \mathrm{M}$ urea and 1X TBE; $90 \mathrm{mM}$ Tris-borate, $\mathrm{pH} 8.3,2.5 \mathrm{mM}$ EDTA). After staining, the gels with ethidium bromide and UV-photography, the RNA was electro transferred to nylon 
membranes, which were later probed for the presence of CARNA 5 as described by White and Kaper, 1989.
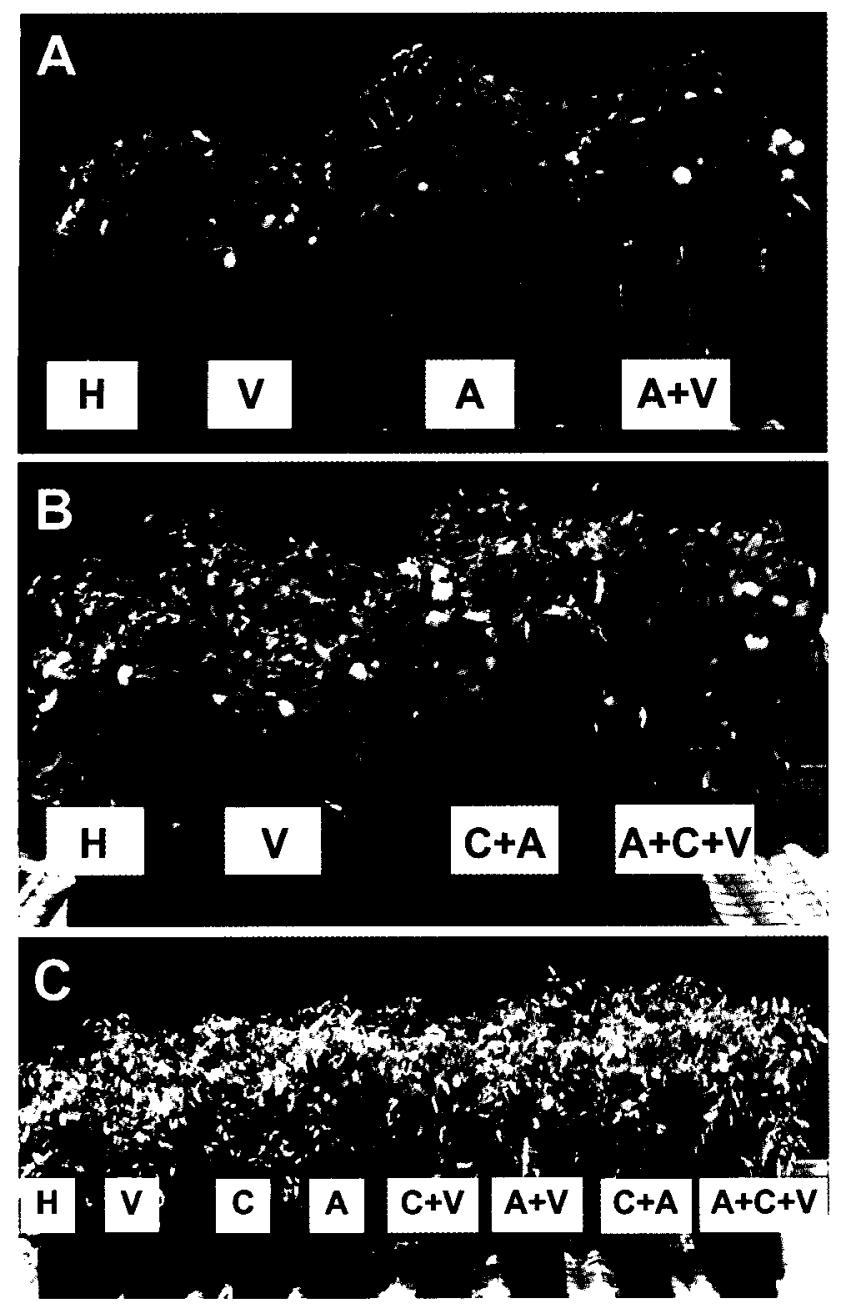

Fig. 1. A) Greenhouse experiment to determine the effects of biofertilizers (Azospirillum and cyanobacterium cultures) on the growth of tomato plants (cultivar UC82B) inoculated with a protective viral strain of CMV (cucumber mosaic virus) associated with CARNA 5 (CMV associated RNA 5) as a biological control agent against viral strains, but it causes a yield reduction in tomato plants. To compensate for the growth and the yield reductions biofertilizers were used in the greenhouse experiment that is showing comparisons of healthy control (negative control) tomato plants $(\mathrm{H})$, inoculated tomato with $\mathrm{CMV}$ associated with CARNA 5 as protective viral strain and as a positive control (V), Azospirillum treated tomato (A) and Azospirillum treated and protective viral strain $(\mathrm{A}+\mathrm{V})$ tomato plants. B) Comparisons of healthy tomato plants $(\mathrm{H})$ with protected $(\mathrm{V})$, cyanobacterium mixed with Azospirillum (C+A), and a mixture of Azospirillum Cyanobacterium treated tomato that were inoculated with the protective viral strain $(\mathrm{A}+\mathrm{C}+\mathrm{V})$. C) General comparisons of healthy control tomato plants $(\mathrm{H})$ with protected $(\mathrm{V})$, Cyanobacterium (C), Azospirillum (A), cyanobacterium and protected $(\mathrm{C}+\mathrm{V})$, Azospirillum and protected $(\mathrm{A}+\mathrm{V})$, cyanobacterium with Azospirillum mixture culture ( $\mathrm{C}+\mathrm{A})$, and Azospirillum mixed with cyanobacterium culture on protected $(\mathrm{A}+\mathrm{C}+\mathrm{V})$ tomato plants.

\section{Results}

Greenhouse experiments. The dry weight of tomato plants indicated that the plant growth was significantly higher in biofertilized non-protected and protected plants than the untreated control plants (Table 1). The maximum plant dry weight was ranged between $9.08 \mathrm{~g} / \mathrm{plant}$ and $8.68 \mathrm{~g} / \mathrm{plant}$ for cyanobacterium treated plants and Azospirillum mixed with cyanobacterium treated tomato plants while the dry weight of untreated protected plants was $6.78 \mathrm{~g} /$ plant.

Fresh weight of tomato fruits was greater for biofertilized protected and non-protected plants than untreated plants. The greatest fruit weight per plant, $1150 \mathrm{~g}$, was for cyanobacterium treated plants, followed by $1040 \mathrm{~g} /$ plant for the cyanobacterium-Azospirillum mixture on protected plants and minimum, $610 \mathrm{~g} / \mathrm{plant}$, was for protected plants. Biofertilized protected and non-protected plants produced more fruits, except for the cyanobacterium treated protected plants that yielded the lowest fruit number/plant (31 fruits/ plant). Maximum fruit number ( 55 fruits/plant) occurred on Azospirillum + cyanobacterium treated plants, in comparison to 37 fruits/plant for cyanobacterium treated protected plants and 35 fruits/plant for healthy control plants as shown in Table 1.

Increased plant growth was observed in plants treated with Azospirillum alone and protected plants treated with Azospirillum compared to the growth reduction observed in both healthy control and protected plants (Fig. 1. A). Cyanobacterium with Azospirillum resulted in a higher growth in both non-protected and protected plants (Fig. 1. B) in comparison to the protected and healthy control plants (Table 1). The maximum dry weight was $9.08 \mathrm{~g} / \mathrm{plant}$, for

Table 1. Effect of biofertilizers on plant growth and fruit yield in tomato plants grown in the greenhouse

\begin{tabular}{lccc}
\hline \hline Treatments $^{\mathrm{a}}$ & $\begin{array}{c}\text { Dry weight } \\
\text { (g/plant) }\end{array}$ & $\begin{array}{c}\text { No. of } \\
\text { Fruits/plant }\end{array}$ & $\begin{array}{c}\text { Fruit yield } \\
\text { (g/plant) }\end{array}$ \\
\hline $\mathrm{H}$ & $7.00 \mathrm{c}$ & $35 \mathrm{cb}$ & $700 \mathrm{cb}$ \\
$\mathrm{V}$ & $6.78 \mathrm{c}$ & $31 \mathrm{c}$ & $610 \mathrm{c}$ \\
$\mathrm{C}$ & $9.08 \mathrm{a}$ & $52 \mathrm{a}$ & $1150 \mathrm{a}$ \\
$\mathrm{A}$ & $7.75 \mathrm{ab}$ & $54 \mathrm{a}$ & $1020 \mathrm{a}$ \\
$\mathrm{C}+\mathrm{A}$ & $8.68 \mathrm{ab}$ & $55 \mathrm{a}$ & $1070 \mathrm{a}$ \\
$\mathrm{C}+\mathrm{V}$ & $7.87 \mathrm{ab}$ & $37 \mathrm{cb}$ & $980 \mathrm{a}$ \\
$\mathrm{A}+\mathrm{V}$ & $8.56 \mathrm{ab}$ & $46 \mathrm{ab}$ & $950 \mathrm{ab}$ \\
$\mathrm{A}+\mathrm{C}+\mathrm{V}$ & $8.40 \mathrm{ab}$ & $44 \mathrm{ab}$ & $1040 \mathrm{a}$ \\
\hline
\end{tabular}

${ }^{\mathrm{a}} \mathrm{H}=$ healthy tomato UC82B plants (negative control); $\mathrm{V}=$ inoculated tomato plants with the protective viral strain of $\mathrm{CMV}$ associated with CARNA 5 (positive control); $\mathrm{C}=$ cyanobacterium treated tomato plants; $\mathrm{A}=$ Azosperillium treated tomato plants grown in the greenhouse.

Values followed by the same letter do not differ significantly from each other at probability level $P=0.05$ according to Student's $t$ test. 
cyanobacterium treated tomatoes, followed by biofertilizers (cyanobacterium and Azospirillum) alone or in combination with protected plants. No significant differences were detected among these treatments. Minimum dry weight was for control and protected plants, with difference between these treatments. Fruit number in these treatments was greater than the Azospirillum inoculated-protected, cyanobacterium plus Azospirillum mixture inoculated-protected and non-protected control plants. A minimum of 31 fruits/ plant resulted from the untreated protected plants (Table 1). Average fresh weight of fruits, per plant, was at the highest rate in biofertilized protected and non-protected plants but it was at the lowest rate in untreated protected plants $(610 \mathrm{~g} /$ plant). There was no difference among those treatments, except Azospirillum treated and protected plants $(950 \mathrm{~g} /$ plant) weighed more than the control plants $(700 \mathrm{~g} /$ plant $)$ and protected plants $(610 \mathrm{~g} / \mathrm{plant})$.

Nitrogen contents and $\mathrm{pH}$ of tomato fruit juice. The nitrogen content was at the highest rate of $223 \mathrm{mg} / \mathrm{plant}$ and $2.79 \%$ nitrogen in plants treated with cyanobacterium and Azospirillum alone without protection, as compared to $140 \mathrm{mg}$ and $2.06 \%$ for untreated protected control plants (Table 2).

There is no any significant differences regarding $\mathrm{pH}$ values in all treatments compared with the healthy control plants. $\mathrm{pH}$ of tomatoes, determined in two sets of three replications, was at the highest rate in cyanobacterium treated and protected plants, showing a value of $\mathrm{pH} 4.48$. $\mathrm{pH}$ was minimum in fruits of protected plants inoculated with the cyanobacterium and Azospirillum mixture, showing a value of $\mathrm{pH} 4.11$ as shown in Table 2. Maximum

Table 2. Effect of biofertilizers on nitrogen content and fruit $\mathrm{pH}$ in tomato plants grown in the greenhouse

\begin{tabular}{lccc}
\hline Treatments $^{\mathrm{a}}$ & $\begin{array}{c}\text { Nitrogen } \\
(\%)\end{array}$ & $\begin{array}{c}\text { Nitrogen } \\
(\mathrm{mg} / \text { plant })\end{array}$ & $\begin{array}{c}\text { Fruit Juice } \\
\mathrm{pH}\end{array}$ \\
\hline $\mathrm{H}$ & $2.16 \mathrm{de}$ & $152 \mathrm{c}$ & $4.20 \mathrm{a}$ \\
$\mathrm{V}$ & $2.06 \mathrm{e}$ & $140 \mathrm{c}$ & $4.30 \mathrm{a}$ \\
$\mathrm{C}$ & $2.46 \mathrm{cb}$ & $223 \mathrm{a}$ & $4.41 \mathrm{a}$ \\
$\mathrm{A}$ & $2.79 \mathrm{a}$ & $216 \mathrm{a}$ & $4.37 \mathrm{a}$ \\
$\mathrm{C}+\mathrm{A}$ & $2.45 \mathrm{cb}$ & $212 \mathrm{ab}$ & $4.25 \mathrm{a}$ \\
$\mathrm{C}+\mathrm{V}$ & $2.60 \mathrm{ab}$ & $205 \mathrm{ab}$ & $4.48 \mathrm{a}$ \\
$\mathrm{A}+\mathrm{V}$ & $2.38 \mathrm{cb}$ & $204 \mathrm{ab}$ & $4.11 \mathrm{a}$ \\
$\mathrm{A}+\mathrm{C}+\mathrm{V}$ & $2.51 \mathrm{cb}$ & $211 \mathrm{ab}$ & $4.11 \mathrm{a}$ \\
\hline
\end{tabular}

${ }^{a} \mathrm{H}=$ healthy tomato $\mathrm{UC82B}$ plants (negative control); $\mathrm{V}=$ inoculated tomato plants with the protective viral strain of CMV associated with CARNA 5 (positive control); $\mathrm{C}=$ cyanobacterium treated tomato plants; $\mathrm{A}=$ Azosperillium treated tomato plants grown in the field.

Values followed by the same letter do not differ significantly from each other at the probability level $P=0.05$ according to Student's $t$ test. nitrogen contents resulted from the cyanobacterium and Azospirillum treated plants, at 223 and $216 \mathrm{mg}$, respectively; these values were greater than the other biofertilizer treatments of protected and non-protected plants. The lowest value occurred for protected and non-protected control plants. Table 1 showed that the maximum nitrogen percentage (2.79\%) occurred in Azospirillum treated plants; the value was greater than those of cyanobacterium inoculated and protected plants, followed by biofertilizer treated and protected plants, and non-protected plants, and then the non-protected control plants. The lowest value ( $2.06 \%$ nitrogen) resulted from the protected control treatment. Number of fruits calculated per ten plants was not different among cyanobacterium plus Azospirillum, Azospirillum alone and cyanobacterium alone treated nonprotected plants.

Field experiments. Tomato fruit yield of field grown tomato plants treated with biofertilizers was determined and compared to untreated control plants. Fresh weight and fruit number were greater for protected biofertilized plants than the non-protected biofertilized plants. Maximum number of fruits resulted from the cyanobacterium and Azospirillum mixture treated protected plants was in average of 204.7. 7.0 fruits per 10 plants. The mean value for the number of fruits yielded from healthy control plants was 124.7 fruits/ 10 plants, and for protected plants was 115 fruits as shown

Table 3. Effect of biofertilizer applications on number of fruits and their fresh weight in field grown tomato plants

\begin{tabular}{lcc}
\hline \hline Treatments $^{\mathrm{a}}$ & Fruit Number $^{\mathrm{b}}$ & Average yield $^{\mathrm{c}}$ \\
\cline { 2 - 3 } & No. $/ 10$ plants & Kg $/ 10$ plants \\
\hline $\mathrm{H}$ & $124.7 \mathrm{a}$ & $27.4 \mathrm{a}$ \\
$\mathrm{V}$ & $115.0 \mathrm{~b}$ & $22.5 \mathrm{~b}$ \\
$\mathrm{C}$ & $136.3 \mathrm{c}$ & $25.7 \mathrm{c}$ \\
$\mathrm{A}$ & $130.0 \mathrm{c}$ & $26.8 \mathrm{~d}$ \\
$\mathrm{C}+\mathrm{A}$ & $130.7 \mathrm{c}$ & $28.7 \mathrm{e}$ \\
$\mathrm{C}+\mathrm{V}$ & $148.7 \mathrm{~d}$ & $39.5 \mathrm{f}$ \\
$\mathrm{A}+\mathrm{V}$ & $200.0 \mathrm{e}$ & $34.0 \mathrm{~g}$ \\
A+C $+\mathrm{V}$ & $204.7 \mathrm{e}$ & $40.0 \mathrm{~h}$ \\
\hline
\end{tabular}

${ }^{\mathrm{a}} \mathrm{H}=$ healthy tomato $\mathrm{UC} 82 \mathrm{~B}$ plants (negative control); $\mathrm{V}=$ inoculated tomato plants with the protective viral strain of CMV associated with CARNA 5 (positive control); $\mathrm{C}=$ cyanobacterium treated tomato plants; $\mathrm{A}=$ Azospirillum treated tomato plants grown in the field.

${ }^{\mathrm{b}}$ Average number of tomato fruits per 10 plants. Three replicas for each treatment of 10 plants each were repeated twice in 2 different sets of experiments.

${ }^{\mathrm{c}}$ Average yield in $\mathrm{kg} / 10$ plants, calculated as average of all 60 plants in each treatment.

Values followed by the same letter do not differ significantly from each other at probability level $P=0.05$ according to the Student's $t$ test. 


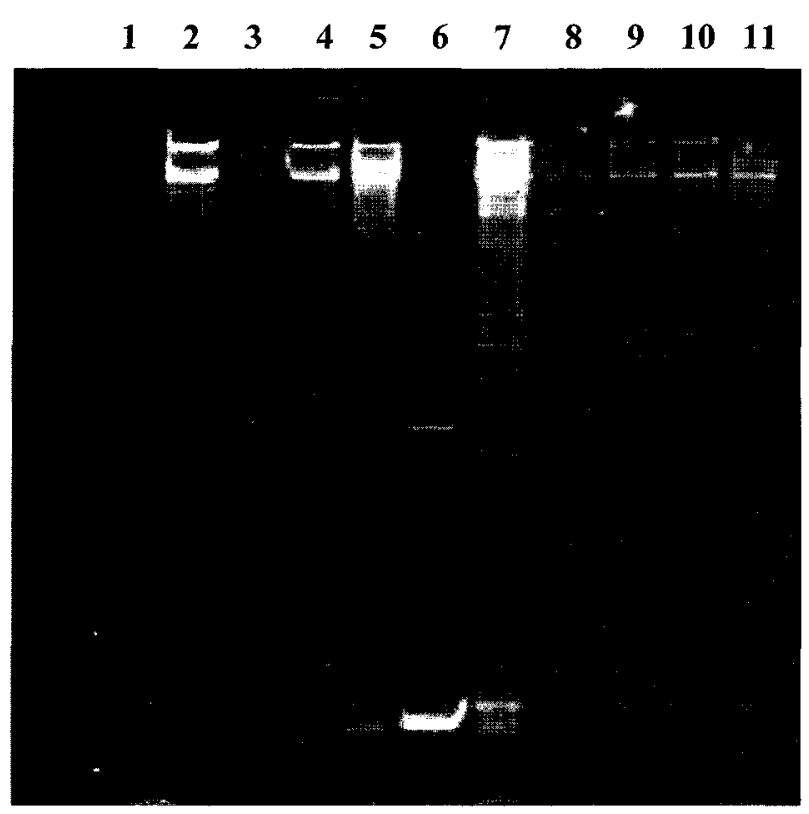

Fig. 2. Polyacrylamide gel $(6 \%)$ showing the presence of CARNA 5 bands in biofertilizer treatments on protected tomato plants. Lanes 1-5 = Samples extracted from one set of replications (A); Lanes 7-11 = Samples extracted from a second set of replications (B). Lane $1=$ Healthy control plant tissues; Lane $2=$ Protected tomato; Lane $3=$ Cyanobacterium on protected plant samples; Lane $4=$ Azospirillum treatment on protected plant sample; Lane 5 = Cyanobacterium mixed with Azospirillum culture on protected plant sample contained CARNA 5; Lane $6=$ Standard CARNA 5; Lane 7 = Cyanobacterium and Azospirillum mixture culture treatment on protected plant sample contained CARNA 5; Lane $8=$ Protected tomato sample; Lane $9=$ Cyanobacterium treatment on protected plant sample; Lane $10=$ Azospirillum treatment on protected plant sample; Lane $11=$ Healthy control. Arrows indicate the presence of CARNA 5 bands.

in Table 3. The highest average of fruit yield $(40 \mathrm{Kg} / 10$ plants) resulted from protected plants treated with both cyanobacterium and Azospirillum mixture, and the minimum $(22.5 \mathrm{Kg} / 10$ plants) resulted from the untreated protected control plants. In general, the fresh weight for biofertilized protected plants was greater than any other treatments. The yield was significantly different than the yield from untreated control plants as shown in Table 3.

Polyacrylamide gel electrophoretic analyses. Tomato samples collected from all treatments were tested for the presence of CARNA 5 associated with the protective strain of CMV. CARNA 5 bands were observed on 6\% polyacrylamide gels at the same molecular weight level of the standard control sample in lane 6, Fig. 2. CARNA 5 bands were observed in extracts of all protected plants, including those treated with cyanobacterium and Azospirillum as shown in Fig. 2. Northern blotting hybridization revealed positive and radioactive signals, indicating the presence of the CARNA 5 bands from treated plant extracts.

\section{Discussion}

Biological control of CMV using satellite-mediated protection in tomato was a previous research work that we already conducted (Montasser et al., 1991, 2006). This resulted in a good protection but with a yield loss of about $20 \%$ in protected tomato. The main objective of this current manuscript is to use the biofertilization and nitrogen fixation to compensate for the yield loss caused by the use of satellitemediated protection.

The genus Azospirillum contains symbiotic nitrogen fixing bacteria that have been used successfully in biofertilization (Kapulnik et al., 1983). Azospirillum strains thrive in root zones and are able to supply biologically fixed nitrogen, which is absorbed by the plants and can lead to improved plant growth (Thakuria et al., 2004). Crop plant root exudates provide nutrients for survival and multiplication of the bacteria (Hamdi, 1982; Kapolunik et al., 1981; Tien et al., 1979; Vlassak et al., 1981). Our work shows a novel application of these biofertilizers, in that they can allow utilization of an antiviral vaccination.

Cyanobacteria are also used in biofertilization, again, because they fix and supply nitrogen to the plants (Muralikrishna et al., 1985; Venkaturaman, 1979). Commonly used species of cyanobacteria are: Anabaena, Nostoc and Tolypothrix. Cyanobacteria occur naturally and do well under moist conditions, generally growing on the soil surface as they are photosynthetic and, as such, require light (Muralikrishna et al., 1985).

The use of cyanobacteria as a soil amendment in agriculture has been well documented (Muralikrishna et al., 1985). Cyanobacteria are non-symbiotic nitrogen fixers and can thus remove dinitrogen gas from the atmosphere and reduce it to ammonium. Cyanobacteria have been inoculated into rice paddy soils for hundreds of years as a means of providing nitrogen to rice (Venkaturaman, 1979). The effect of the inoculation of three treatments of nitrogen fixing cyanobacteria (Aulosira fertilissima, Nostoc muscarum, or a mixture of the two) was investigated by Saha and Mandal (1980). These authors found that inoculation increased rice (Oryza sativa) grain and straw yield, and nitrogen uptake into the grain. The efficiency of inoculation, however, gradually decreased with the increase in levels of nitrogen in the paddy soils.

Because inoculation of rice with cyanobacteria has clearly been shown to be a beneficial process, researchers have wondered whether inoculation of soils directly could increase the yield of vegetable crops. To examine this question (Rodgers et al., 1979) demonstrated that 
inoculation of soils containing radish or tomato plants with algal suspensions increased growth rates of both plants and increased their overall yield. Alternatively, Tiedemann et al. (1980) studied the effect of applying a commercial cyanobaterial inoculant, either live or killed, to soils in a greenhouse pot experiment using orchard grass (Dactylis glomerata), pine grass (Equisetum arvense), douglas fir (Pseudotsuga menziesii), and ponderosa pine (Pinus ponderosa). It was observed that inoculated plants have greater biomass yields than the uninoculated control. It was found, however, that the "killed" and living inoculants had effects that were not different from each other. The response to the inoculant, compared to the control, thus appeared to be a result of the addition of nutrients present in the inoculant stock solution.

Biofertilizers are ecofriendly inputs and are less damaging to the environment than inputs such as chemical fertilizers (Kannaiyan et al., 2004; Nuttall, 2006). In the present investigation inoculation with cyanobacteria and/or azospirillum showed increased fresh weight of fruits and dry weight of protected tomato plants. Overall, the plant growth, fruit yield, and nitrogen contents were increased by biofertilizer inoculations, in comparison to non-protected and protected control plants without biofertilizer inoculations. This result is in agreement with the reports by Rao and Charyulu (2005) who showed increased plant height, dry weight of shoot and root, and total nitrogen content of shoot, root and grain by inoculating foxtail millet with three strains of Azospirillum either alone or in combination with nitrogen fertilizer. Growth-stimulating compounds or nitrogen fixation organisms are the reasons for yield increase. Okon and Labandera-Gonzalez (1994) concluded that various strains of $A$. brasilense and A. lipoferum are capable of promoting the yield of agriculturally important crops in a range of soil types and climatic conditions. Use of multiple inoculations can enhance total seasonal $\mathrm{N}_{2}$ fixation, $\mathrm{P}$ uptake, and mineral nutrition in general, but they can also help in controlling plant pathogens. These bio input can allow reductions in chemical inputs, such as fertilizers and pesticides, that are expensive and environmentally unsound. If populations of the inoculated organisms can be established in agricultural soils, the interval between biofertilizer applications could be increased and costs further lowered (Rai et al., 2000). Bashan and Holguin (1997) have reviewed several examples of co-inoculation with Azospirillum and Rhizobium, Azotobacter, Arthrobacter, Enterobacter, or Klebsiella.

Our studies indicated the presence of CARNA 5 in biofertilizered protected plants and the northern blot hybridization results confirmed the gel electrophoresis analyses (White and Kaper, 1989). This proved that biofertilization did not affect the accumulation of viral satellite
RNA required for the plant protection. At the same time, the biofertilization compensated for the potential negative effects of inoculation, in the absence of CMV. Thus, viral satellite CARNA 5 can be used as a biological control agent along with nitrogen biofixing agents (both cyanobacteria and Azospirillum spp.). This work shows that a set of two biological inputs, together, can be used to provide good crop growth and high quality fruits, allowing reductions in chemical fertilizer inputs. The biofertilization used was a success, and the tomato fruit yield was significantly increased compared to untreated plants inoculated with the protective viral strain associated with CARNA 5 alone.

\section{Acknowledgment}

We thank Drs. S. Kotob and F. Hashem for facilitating the field activities and for providing the cultured Azospirillum and cyanobacterial strains to be applied directly in both greenhouse and field experiments.

\section{References}

Burris, R. B. 1977. A synthesis paper on non-leguminous $\mathrm{N}_{2}$-fixing system. In Recent developments in nitrogen-fixation. ed. by W. A. Newton, J. R. Postgate and C. Roddrigues-Barruaco. pp. 487-513. Academic Press, London.

Bashan, Y. and Holguin, G. 1997. Azospirillum-plant relationships. Environmental and physiological advances (19901996). Can. J. Microbiol. 43:103-121.

Caballero-Mellado, J., Carcano-Montiel, M. and MascaruaEsparza, M. A. 1993. Field inoculation of wheat (Triticum aestivum) with Azospirillum brasilense under temperate climate. Symbiosis 13:243-253.

Gallitelli, D., Vovlas, C., Martelli, G., Montasser, M. S., Tousignant, M. E. and Kaper, J. M. 1991. Satellite-mediated protection of tomato against cucumber mosaic virus: II. Field test under natural epidemic conditions in southern Italy. Plant Dis. 75:93-95.

Gentili, F. and Jumpponen, A. 2006. Potential and possible uses of bacterial and fungal biofertilizers. In Handbook of microbial biofertilizers. ed. by M. K. Rai. p. 543. The Haworth press, New York.

Gupta, S., Arora, D. K. and Srivastava, A. K. 1995. Growth promotion of tomato plants by rhizobacteria and imposition of energy stress on Rhizoctonia solani. Soil Biol. Biochem. 27:1051-1058.

Hamdi, Y. A. 1982. Application of nitrogen-fixing systems in soil management. FAO Soils Bulletin 49:88.

Kannaiyan, S., Kumar, K. and Govindarajan, K. 2004. Biofertilizers technology for rice based cropping. Jodhpur, Scientific. Xviii, 450 pp.

Kapolnik, Y. A., Kigel, J., Okon, Y., Nur, I. and Henis, Y. 1981. Effects of Azospirillum inoculation on some growth parameters and N-content of wheat sorghum and panicum. Plant Soil 
61:65-70.

Kapulnik, Y., Sarig, S., Nur, I. and Okon, Y. 1983. Effect of Azospirillum inoculation on yield of field-grown wheat. Can. J. Microbiol. 29:895-899.

Kotob, S. I., Hashem F. M., Montasser, M. S. and Kaper, J. M. 1990. Utilization of biofertilizers compensates for yield reduction of protected tomato plants. In Nitrogen fixation: Achievements and Objectives. Proceedings of the $8^{\text {th }}$ International Congress on Nitrogen Fixation, Knoxville, Tennessee, USA. p. 660.

Lot, H., Marrou, J., Quiot, J. B. and Evan, C. 1972. A contribution to the study on cucumber mosaic virus (CMV) II. Quick method of purification. Ann. Phytopathol. 4:25-38.

Montasser, M. S., Tousignant, M. E. and Kaper, J. M. 1991. Satellite-mediated protection of vegetable crops against cucumber mosaic virus. I. Protection of tomato in the greenhouse and under simulated epidemic conditions in the field. Plant Dis. 75:86-92.

Montasser, M. S. 1999. Experimental Protocols in Virology and Immunology. Academic Publication Council, Kuwait University, Kuwait.

Montasser, M. S., Al-Hamar, B. and Bhardwaj, R. G. 2006. Biological control of a severe viral strain using a benign viral satellite RNA associated with cucumber mosaic virus. Plant Pathology J. 22:131-138.

Muralikrishna, P. V. G., Megharaj, M. and Venkateswarlu, K. 1985. Occurrence of soil algae as influenced by profile depth and amendments. Phykos: J. Phycol. Soc. 24:42-45.

Neyra, C. A. and Dobereiner, J. 1977. Nitrogen fixation in grasses. Adv. Agron. 29:1-38.

Nuttall, N. 2006. Soil biodiversity key to environmentally friendly agriculture. Below ground biodiversity-from worms to bacteria-key to environmentally friendly agriculture. The $8^{\text {th }}$ Conference of the Parties to the Convention on Biological Diversity, Curitiba, Brazil.

Okon, Y. and Labandera-Gonzalez, C. A. 1994. Agronomic application of Azospirillum. An evaluation of 20 years worldwide field inoculation. Soil Biol. Biochem. 26:1591-1601.

Rai, A. N., Soderback, E. and Bergman, E. 2000. Cyanobacterium-plant symbiosis. New Phytology. 147:449-481.

Rao, K. V. B. and Charyulu, P. B. N. 2005. Evaluation of effect of inoculation of Azospirillum on the yield of Staria italica (L.). Afri. J. Biotechnol. 4:989-995.

Rodgers, G. A., Bergman, B., Henriksson, E. and Udris, H. 1979. Utilization of blue-green algae as biofertilizers. Plant Soil 52:99-107.

Saha, K. C. and Mandal, L N. 1980. A greenhouse study on the effect of inoculation of $\mathrm{N}$-fixing blue-green algae in a soil treated with $\mathrm{P}$ and $\mathrm{Mo}$ on the yield of rice and changes in the N-content of soil. Plant Soil 57:23-30.

Thakuria, D., Talukdar, N. C., Goswami, C., Hazarika, S., Boro, R. C. and Khan, M. R. 2004. Characterization and screening of bacteria from rhizosphere of rice grown in acidic soils of Assam. Curr. Sci. 86:7.

Tiedeman, A. R., Lupushinsky, W. and Larsen, H. J. 1980. Plant and soil response to a commercial blue-green algae inoculant. Soil Biol. Biochem. 12:471-475.

Tien, P. O., Zhang, X., Qiu, B., Qin, B. and Wu, G. 1987. Satellite RNA for the control of plant diseases caused by cucumber mosaic virus Ann. Appl. Biol. 111:143-152.

Tien, T. M., Gaskins, M. H. and Hubbeli, D. H. 1979. Plant growth substances produced by Azospirillum brasilense and their effect on the growth of pearl millet (Pennisetum amercanum L.). Appl. Environ. Microbiol. 37:1016-1024.

Venkataraman, G. S. 1979. Blue-green algae in rice cultivation, an evaluation. Glimpses Plant Res. 4:74-81.

Vlassak, K. and Reynders, L. 1981. Azospirillum rhizocoenoses in agricultural practice. In Current perspectives in nitrogen fixation. ed. by A. H. Gibson and W. E. Newton. Australian Academy of Science, Canberra.

White, J. L. and Kaper, J. M. 1989. A simple method for detection of viral satelliteRNAs in small plant tissue samples. J. Virol. Methods 23:83-9. 